ORIGINAL ARTICLE / ARTIGO ORIGINAL

\title{
HIV testing coverage among female sex workers, Brazil, 2016
}

\author{
Cobertura de teste anti-HIV entre mulheres trabalhadoras do sexo, Brasil, 2016 \\ Ana Maria de Brito' (D), Célia Landmann Szwarcwald", Giseli Nogueira Damacena", \\ Inês Costa Dourado"', The Brazilian FSW Group*
}

\begin{abstract}
Introduction: Knowing the factors associated with periodic HIV testing among female sex workers (FSW) is essential to expand testing coverage and to broaden programs of treatment as prevention. Methods: We used data from 4,328 FSWs recruited by the respondent-driven sampling (RDS) method in 12 Brazilian cities in 2016. Data analysis considered the complex sampling design. The prevalence of $\mathrm{HIV}$ testing in the last year and periodic HIV test were estimated. Factors associated with regular HIV testing were identified through logistic regression models. Results: The testing coverage in the last year was 39.3\%. Only $13.5 \%$ of FSW reported having performed a periodic HIV test in the last year. Among the factors associated with the higher probability of HIV testing in the last year were a better level of education, living with a partner, working indoors, consistent use of condoms, and regular use of public and private health services stood out. Discussion: Periodic HIV testing allows early diagnosis and immediate treatment of cases, reducing the chances of spreading the infection to the population. However, factors such as stigma and discrimination hinder the use of regular health services. Conclusion: It is necessary to expand awareness campaigns, especially among FSWs with low educational level and greater vulnerability, in order to broaden the perception of risk and the importance of periodic testing, in addition to encouraging regular health care.
\end{abstract}

Keywords: Sex workers. RDS. HIV Serodiagnoses. Associated factors. Brazil.

\footnotetext{
*Célia Landmann Szwarcwald, Paulo Roberto Borges de Souza Júnior, Orlando C. Ferreira Jr., Giseli Nogueira Damacena, Neide Gravato da Silva, Rita Bacuri, Helena Brigido, Hermelinda Maia Macena, Ana Brito, Inês Dourado, Mark Drew Crosland Guimarães, Wanessa da Silva de Almeida, Alexandre Grangeiro, Carla Luppi, Karin Regina Luhm, Isete Maria Stella, Adriana Varela Espinola, Tânia Varela, and Francisca Sueli da Silva.

'Department of Collective Health, Aggeu Magalhães Institute, Oswaldo Cruz Foundation - Recife (PE), Brazil.

"Institute of Scientific and Technological Communication and Information in Health, Oswaldo Cruz Foundation - Rio de Janeiro (RJ), Brazil. I'Department of Collective Health, Federal University of Bahia - Salvador (BA), Brazil.

Corresponding author: Ana Maria de Brito. Departamento de Saúde Coletiva (Nesc). Instituto Aggeu Magalhães. Avenida Moraes Rego, s/n, Cidade Universitária, CEP: 50670-420, Recife, PE, Brasil. E-mail: anabrito1009@gmail.com

Conflict of interests: nothing to declare - Financial support: United Nations Educational, Scientific and Cultural Organization (UNESCO).
} 
RESUMO: Introdução: Conhecer os fatores associados ao teste periódico de HIV no grupo de mulheres trabalhadoras do sexo (MTS) é fundamental para expandir a cobertura de testagem e ampliar os programas de tratamento como prevenção. Métodos: Foram utilizados dados de 4.328 MTS recrutadas pela metodologia respondent-driven sampling (RDS) em 12 cidades brasileiras em 2016. A análise de dados considerou o desenho complexo de amostragem. Foram estimadas as prevalências de realização do teste de HIV no último ano e do teste periódico. Através de modelos de regressão logística foram identificados fatores associados à testagem regular de HIV. Resultados: A cobertura de teste no último ano foi de 39,3\%. Apenas 13,5\% das MTS relataram ter realizado teste periódico de HIV no último ano. Entre os fatores associados à maior probabilidade de realização de teste de HIV no último ano, destacaram-se o melhor nível de instrução, o fato de morar com companheiro, trabalhar em lugares fechados, o uso consistente de preservativo, e o uso regular de serviço de saúde público e privado. Discussão: A realização periódica de teste de HIV possibilita o diagnóstico precoce e o tratamento imediato dos casos, reduzindo as chances de disseminação da infecção na população. Entretanto, fatores como estigma e discriminação dificultam o uso regular de serviços de saúde. Conclusão: É necessário expandir campanhas de conscientização, sobretudo entre as MTS de baixo nível de instrução e maior vulnerabilidade, a fim de ampliar a percepção de risco e da importância da testagem periódica, além de incentivar os cuidados regulares de saúde.

Palavras-chave: Profissionais do sexo. RDS. Sorodiagnóstico de HIV. Fatores associados. Brasil.

\section{INTRODUCTION}

Despite preventive measures widely adopted in recent years to reduce the spread of the infection by the acquired immunodeficiency virus (HIV) and other sexually transmitted infections (STIs) among female sex workers (FSW), this population segment continues being disproportionately affected by HIV ${ }^{1}$.

From an epidemiological point of view, unprotected sexual practices and the multiplicity of partnerships are important determinants for a greater exposure to $\mathrm{HIV}^{2}$. In addition, other STIs act as co-factors for HIV transmission ${ }^{3,4}$. From social perspective, structural characteristics, including environment, violence, stigma, cultural contexts and contexts of illegality of sex work continue to be a crucial part in determining the risk of infection among sex workers and their clients 5 .

In Brazil, it is estimated that FSWs represent $0.8 \%$ of the female population between 15 to 49 years, corresponding to half a million women, approximately ${ }^{6}$. Although prostitution is not considered a crime according to Brazilian law, except if women under the age of 18 years are involved, FSWs constantly experiment discrimination, condemnatory, moralistic and punitive attitudes ${ }^{7}$, in addition to physical and sexual violence - factors that are consistently associated with adverse health outcomes ${ }^{8}$.

Since the onset of HIV/AIDS epidemy in Brazil, in the 1980s, the prevalence of HIV has remained in levels below $1 \%$ in the general population has been "concentrated", with higher rates among key-populations, such as FSWs'. The prevalence rate of HIV for FSWs was estimated in some researches conducted in the country ${ }^{10,11}$, 
being always much higher than the general female population ${ }^{12}$. A review and meta-analysis study ${ }^{13}$ jointly investigated 8 Brazilian researches, totaling 3,625 female sex workers. The combined prevalence was estimated in $5.1 \%$. In a biological and behavioral survey conducted in 10 Brazilian cities, in 2009, the prevalence of HIV was estimated in $5 \%{ }^{14}$, and in a survey of 2016 , performed with similar methodology, the prevalence of HIV remained in the same level ${ }^{15}$.

Currently, periodic HIV testing is a public health priority, especially among key-populations, such as FSWs, and the Ministry of Health recommends that it should be performed with a semiannual periodicity ${ }^{16}$. According to the Joint United Nations Programme on HIV / AIDS (UNAIDS), the 90-90-90 target establishes that, until 2020, 90\% of all people living with HIV should know their serological status, $90 \%$ of all people with HIV diagnosis should receive antiretroviral treatment, and $90 \%$ of all the people receiving antiretroviral treatment should reach suppression of viral load ${ }^{17}$.

In this sense, the HIV test constitutes the gateway to HIV prevention and treatment, since it allows the early identification and treatment of the cases, reducing the negative impact of the disease on the individual, and it is strategic for prevention, since it decreases the chances of new infections ${ }^{18}$. However, although the access to testing has increased in recent years, regular HIV tests in the high-risk populations continue to be a challenge in several countries. To know the factors associated with periodically getting tested for HIV test is fundamental to expand testing coverage and to expand treatment as prevention programs (TasP) ${ }^{19}$.

This study aims to estimate the prevalence of last year HIV testing and periodic testing, and to investigate factors associated with HIV testing coverage in the last 12 months among FSWs in Brazil.

\section{METHODS}

In Brazil, in 2016, a biological and behavioral survey was conducted using the respondent-driven sampling (RDS) methodology to recruit FSWs, in order to estimate the prevalence rate of HIV, syphilis and hepatitis B and C; and to identify knowledges, attitudes and practices related to infection by HIV and other SDIs.

The survey was conducted in 12 Brazilian cities (Manaus, Belém, Fortaleza, Recife, Salvador, Belo Horizonte, São Paulo, Rio de Janeiro, Campo Grande, Brasília, Curitiba and Porto Alegre), chosen by the Departamento de Vigilância, Prevenção e Controle das IST, Aids e Hepatites Virais (DIAHV - Department of Surveillance, Prevention and Control of STIs) both for geographic criteria and by its relevance in the HIV/AIDS epidemy in the country. In each city, the minimum sample size was established at 350 FSWs.

Women were considered eligible to participate in the study based on the following inclusion criteria: being a woman (gender biologically determined at birth); being 18 years old or older; having had commercial sex in the last 4 months prior to the research; having accepted to participate in the study; having a valid invitation for the research. 
In each of the 12 cities, 5 to 10 seeds were selected, non-randomly, after formative qualitative research. Each seed received 3 coupons to distribute to other FSWs within their social network. After participating in the interview, each participant also received 3 coupons to distribute to their peers, and this process was repeated until the sample size was reached in each city. We used primary (snacks, giveaways and reimbursement of transport) and secondary incentives, for the recruitment of other participants.

The socio-behavioral questionnaire was composed of closed multiple choice questions and included the following topics: sociodemographic and sex work characteristics; knowledge about HIV transmission and other STIs; social support and access to educational and preventive materials; HIV, syphilis, and hepatitis B and C testing; health status, health assistance and sexually transmitted diseases; violence; sexual behavior with fixed partners and clients; and use of alcohol and drugs.

HIV, syphilis, hepatitis B and C testing was performed through quick standardized tests, using peripheral venous blood collection, according to the protocols recommended by the Brazilian Ministry of Health ${ }^{4}$.

For data analysis, the complex sampling design of the recruitment by RDS was considered, also considering the dependence between the observations, resulting from the recruitment chains, and the unequal selection probabilities, due to the different network sizes of each participant. Each city composed a stratum and, in each city, weighting was inversely proportional to the size of the network, totaling the size of the stratum. In order to consider the homophilia effect - that is, the tendency of one participant to recruit peers with similar characteristics-, the three participants invited by the same recruiter were considered as a cluster ${ }^{14}$. The analyses were performed using the SPSS statistical software, version $21.0^{20}$.

In this study, two outcomes were considered: "proportion of FSWs who underwent HIV testing in the last 12 months prior to the research"; and "proportion of FSWs who underwent HIV testing in the last 12 months prior to the research because they get tested periodically", after analysis of the reasons reported for getting the last HVI test.

To analyze the possible factors associated with the two outcomes, the following sociodemographic and sexual work characteristics were considered: age group (18 to $24 ; 25$ or older); schooling level (some primary school; some middle school; some high school, complete high school; incomplete undergraduate education or a higher level); monthly income ( $\mathrm{R} \$ 500.00$; greater than R\$ 501.00); lives with a partner (yes; no); workplace (bars and nightclubs; other places indoors; street points).

To investigate the association of the outcomes with other preventive practices, the following factors were considered: if they use condoms with their clients (always uses condoms with clients in vaginal sex: yes; no); and if they would accept not using a condom with their clients (would accept not using condoms with clients with any situation: yes; no), created from the questionnaire question "In what situations would you accept having sex without condoms with costumers?", with the following answer options: when she already knows the client; by request or demand of the client; when she needs money very much; when she makes many calls on the same day; when she 
has an allergy (irritation) from the condom; when there is no condom at the time of the call; when she is not conscious due to drug or alcohol use; another reason.

To analyze the association between HIV testing and regular use of health services, the following options were considered: no; public; and private - corresponding, respectively, to not making regular use of health services; regular use of public health service; and regular use of private health service.

Bivariate and multivariate logistic regressions were performed, having as response variables, firstly, the HIV test coverage in the last year prior to the research and, subsequently, the periodic HIV test coverage in the year prior to the research. As a measure of association, odds ratio (OR) was used.

This research project was approved by the Research Ethics Committee of the Oswaldo Cruz Foundation (Protocol 1.338.989) and followed the guidelines of the National Health Council, ensuring voluntariness, anonymity and the possibility of interrupting participation at any time in the study, through the signing of the Term of Free and Informed Consent (TFIC).

\section{RESULTS}

Among the 4,328 recruited in the study, 4,245 women 18 years or older were included in the analysis, after excluding the seeds. Of the total of studied FSWs, $66.3 \%$ were 25 years or older; $73.8 \%$ had not completed high school; $27.4 \%$ had a monthly income of up to R\$ 500.00 ; and $12.9 \%$ lived with a partner. In relation to the workplace, $14 \%$ worked in bars and nightclubs, $46.6 \%$ in street points, and $39.4 \%$ in other places. Of the total, $80.5 \%$ reported always using condoms during vaginal sex with clients, and $37.4 \%$ would accept having sex without condoms with their clients. Regarding the regular use of health services, $56.6 \%$ used the public service, $4.6 \%$ used private service, and $38.8 \%$ reported not using any health service.

Of the studied FSWs, $77.3 \%$ had already undergone a HIV test in their lives; $39.3 \%$ had undergone at least one HIV test in the last 12 months prior to the research; and $38.0 \%$ had been tested more than 12 months ago. Only $13.5 \%$ of the FSWs got tested for HIV in the last 12 months because they do the test periodically (Table 1).

Table 1. Prevalence of HIV test according to the time of the last test. RDS-FSW, Brazil, 2016.

\begin{tabular}{l|c|c}
\hline When did you last get tested for HIV? & Prevalence & $95 \% \mathrm{Cl}$ \\
\hline Never had it & 22.7 & $(21.0-24.3)$ \\
\hline Did it in the last 12 months prior to the research & 39.3 & $(37.4-41.2)$ \\
\hline Because she is tested periodically & 13.5 & $(23.4-26.8)$ \\
\hline For another reason & 25.8 & $(36.2-40.0)$ \\
\hline Did it more than 12 months before the research & 38.0 & \\
Cl: confidence interval. & &
\end{tabular}


Among the FSWs that got tested in the 12 months before the research, 15.4\% got tested in their prenatal, $34.6 \%$ because they did it periodically, and $36 \%$ because they felt exposed to risks. As for FSWs who had never tested for HIV (22.7\%), the main reasons were: not feeling at risk (16.6\%); not seeing reason to perform the test $(23.7 \%)$; not knowing where to get it (8.5\%); being afraid (21.9\%); or being ashamed (12.1\%) of getting the test.

The prevalence of HIV testing in the last 12 months and the results of the bivariate logistic regression with the factors considered in the study are shown in Table 2. The findings reveal a positive and statistically significant gradient in the HIV testing coverage in the last year as the level of schooling increases. A significant growth in the proportion of testing is observed as income increases. The HIV testing coverage in the last 12 months among those who live with a partner is $44.9 \%$, significantly higher than among those who do not (38.45). The proportion of street workers who got tested in the last 12 months was $37.4 \%$, which is significantly lower than that found among FSWs who work in bars and nightclubs (45.8\%). There was no significant association with age groups.

The results of Table 2 also show that there is a statistically significant association between the HIV testing coverage in the last year and other preventive practices: this coverage was significantly greater among FSWs who reported using condoms regularly with clients (OR: 1.421) and among those who would not accept not using condoms with clients in any situation $(\mathrm{OD}=1.413)$. In the analysis of association with the regular use of health services, the greater coverage of the HIV test in the last year was in the private service $(57.7 \%)$, followed by the public service $(40.6 \%)$, being the lowest recorded coverage $(35.3 \%)$ for those who reported not using health services regularly, with statistically significant odds ratios of 2.509 and 1.255 , respectively, when compared to those who do not use any health service regularly (Table 2).

The results of multivariate logistic regression, considering getting tested for HIV in the last 12 months as outcome, are shown in Table 3. Age groups were not considered, since there was not a significant association in the bivariate modeling. Even after including all factors in the regression, the gradient for the schooling level remained, with significant odds ratios for all levels of education (except for some middle school) and also for the income of $\mathrm{R} \$ 501.00$ or more. The fact of not accepting not using condoms with clients in any situation remained statistically significant ( $O R=1.284$ ), as well was having a regular public $(O R=1.338)$ or private $(O R=2.072)$ source of care.

Table 4 shows the results of the bivariate logistic regression models, with the response variable as the periodic HIV testing. The analysis by age group shows that the FSWs aged 18 to 24 years old have periodic testing coverage of only $9.7 \%$, significantly lower than the one found among the FSWs aged 25 years or older. The association between periodic testing and level of education were statistically significant from complete high school and for the monthly income of R\$ 501.00 or more. The FSWs from bars and nightclubs had a periodic testing coverage of $19.1 \%$, significantly higher $(\mathrm{OR}=1.820)$ than the one found among FSWs who worked at street points $(11.5 \%)$. The women 
Table 2. Prevalence of HIV test in the last year prior to the survey and respective odds ratios for study variables. RDS-FSW, Brazil, 2016.

\begin{tabular}{|c|c|c|c|c|c|}
\hline & \multirow{2}{*}{$\begin{array}{c}\text { Variables } \\
\%\end{array}$} & \multicolumn{4}{|c|}{ HIV test in the last year } \\
\hline & & $95 \% \mathrm{Cl}$ & OR & $95 \% \mathrm{Cl}$ & \\
\hline \multirow[t]{2}{*}{ Age group } & 18 to 24 years old & 37 & $(33.7-40.5)$ & 1.000 & - \\
\hline & 25 or older & 40.4 & $(38.1-42.8)$ & 1.115 & $(0.969-1.376)$ \\
\hline \multirow{5}{*}{$\begin{array}{l}\text { Schooling } \\
\text { level }\end{array}$} & Some primary school & 32.1 & $(27.4-37.3)$ & 1.000 & - \\
\hline & Some middle school & 32.7 & $(29.4-36)$ & 1.025 & $(0.783-1.341)$ \\
\hline & Some high school & 42 & $(38.4-45.8)$ & 1.531 & $(1.167-2.008)$ \\
\hline & High school & 46.7 & $(42.3-51.2)$ & 1.851 & $(1.388-2.470)$ \\
\hline & $\begin{array}{l}\text { Incomplete undergraduate } \\
\text { education or a higher level }\end{array}$ & 55 & $(47.7-62.2)$ & 2.586 & $(1.793-3.729)$ \\
\hline \multirow{2}{*}{$\begin{array}{l}\text { Monthly } \\
\text { income }\end{array}$} & $\leq \mathrm{R} \$ 500.00$ & 31.1 & $(27.6-34.9)$ & 1.000 & - \\
\hline & $\mathrm{R} \$ 501.00$ or more & 42 & $(39.7-44.3)$ & 1.603 & $(1.321-1.945)$ \\
\hline \multirow{2}{*}{$\begin{array}{l}\text { Lives with a } \\
\text { partner }\end{array}$} & No & 38.4 & $(36.4-40.5)$ & 1.000 & - \\
\hline & Yes & 44.9 & $(39.6-50.3)$ & 1.303 & $(1.031-1.647)$ \\
\hline \multirow[t]{3}{*}{ Place of work } & Street & 37.4 & $(34.6-40.3)$ & 1.000 & - \\
\hline & Bars or nightclubs & 45.8 & $(40.8-50.9)$ & 1.413 & $(1.111-1.797)$ \\
\hline & Other indoor spaces & 39.2 & $(36-42.4)$ & 1.077 & $(0.896-1.293)$ \\
\hline \multirow{2}{*}{$\begin{array}{l}\text { Uses condoms } \\
\text { with clients }\end{array}$} & No & 32.7 & $(28.5-37.2)$ & 1.000 & - \\
\hline & Yes & 40.8 & $(38.7-42.9)$ & 1.421 & $(1.146-1.762)$ \\
\hline \multirow{2}{*}{$\begin{array}{l}\text { Accepts not } \\
\text { using condom } \\
\text { with clients }\end{array}$} & Yes & 34.2 & $(31.1-37.4)$ & 1.000 & - \\
\hline & No & 42.3 & $(39.9-44.8)$ & 1.413 & $(1.189-1.679)$ \\
\hline \multirow{3}{*}{$\begin{array}{l}\text { Regular use } \\
\text { of health } \\
\text { services }\end{array}$} & No & 35.3 & $(32.4-38.3)$ & 1.000 & - \\
\hline & Public & 40.6 & $(38-43.2)$ & 1.255 & $(1.061-1.484)$ \\
\hline & Private & 57.7 & $(49.3-65.7)$ & 2.509 & $(1.743-3.612)$ \\
\hline
\end{tabular}

$\mathrm{Cl}$ : confidence interval; OR: odds ratio.

who reported living with a partner had a lower chance of getting periodically tested than the ones who do not $(\mathrm{OR}=0.668)$.

In Table 4, additionally, the statistically significant association between the periodic HIV testing and other preventive practices stands out, with higher proportions of periodic testing among women who always use condoms with clients during vaginal sex $(\mathrm{OR}=2.384)$ and among those who would not accept not using condoms with clients 
in any situation $(\mathrm{OR}=1.696)$. In addition, having a usual source of care, whether public or private, was one of the main factors associated to periodic HIV testing, with odds ratios of 1.639 and 4.079 , respectively.

Table 3. Multivariate analysis of the association between study variables and prevalence of HIV testing in the last year prior to the survey. RDS-FSW, Brazil, 2016.

\begin{tabular}{|c|c|c|c|}
\hline & \multirow{2}{*}{$\begin{array}{l}\text { Variables } \\
\text { OR }\end{array}$} & \multicolumn{2}{|c|}{ HIV test in the last year } \\
\hline & & $95 \% \mathrm{Cl}$ & \\
\hline \multirow{5}{*}{ Schooling level } & Some primary school & 1.000 & - \\
\hline & Some middle school & 1.016 & $(0.756-1.366)$ \\
\hline & Some high school & 1.491 & $(1.091-2.037)$ \\
\hline & High school & 1.743 & $(1.244-2.443)$ \\
\hline & $\begin{array}{l}\text { Incomplete undergraduate education } \\
\text { or a higher level }\end{array}$ & 2.460 & $(1.619-3.737)$ \\
\hline \multirow{2}{*}{ Monthly income } & $\leq \mathrm{R} \$ 500.00$ & 1.000 & - \\
\hline & $\mathrm{R} \$ 501.00$ or more & 1.338 & $(1.077-1.663)$ \\
\hline \multirow{2}{*}{$\begin{array}{l}\text { Lives with a } \\
\text { partner }\end{array}$} & No & 1.000 & - \\
\hline & Yes & 1.245 & $(0.968-1.603)$ \\
\hline \multirow{3}{*}{ Place of work } & Street & 1.000 & - \\
\hline & Bars or nightclubs & 1.007 & $(0.767-1.321)$ \\
\hline & Other indoor spaces & 0.783 & $(0.633-0.969)$ \\
\hline \multirow{2}{*}{$\begin{array}{l}\text { Uses condoms } \\
\text { with clients }\end{array}$} & No & 1.000 & - \\
\hline & Yes & 1.119 & $(0.865-1.447)$ \\
\hline \multirow{2}{*}{$\begin{array}{l}\text { Accepts not using } \\
\text { condoms with } \\
\text { clients }\end{array}$} & Yes & 1.000 & - \\
\hline & No & 1.284 & $(1.044-1.579)$ \\
\hline \multirow{3}{*}{$\begin{array}{l}\text { Regular use of } \\
\text { health services }\end{array}$} & No & 1.000 & - \\
\hline & Public & 1.338 & $(1.113-1.609)$ \\
\hline & Private & 2.072 & $(1.406-3.053)$ \\
\hline
\end{tabular}

Cl: confidence interval; OR: odds ratio. 
Table 4. Prevalence of periodic HIV testing in the last year prior to the survey and respective odds ratios for study variables. RDS-FSW, Brazil, 2016.

\begin{tabular}{|c|c|c|c|c|c|}
\hline & \multirow{2}{*}{$\begin{array}{c}\text { Variables } \\
\%\end{array}$} & \multicolumn{4}{|c|}{ Periodic HIV testing in the last year } \\
\hline & & $95 \% \mathrm{Cl}$ & OR & $95 \% \mathrm{Cl}$ & \\
\hline \multirow{2}{*}{ Age group } & 18 to 24 years old & 9.7 & $(7.9-11.8)$ & 1.000 & - \\
\hline & 25 or older & 15.4 & $(13.8-17.2)$ & 1.702 & $(1.311-2.209)$ \\
\hline \multirow{5}{*}{ Schooling level } & Some primary school & 11.1 & $(8-15.2)$ & 1.000 & - \\
\hline & Some middle school & 9.4 & $(7.6-11.5)$ & 0.828 & $(0.537-1.277)$ \\
\hline & Some high school & 12.7 & $(10.5-15.3)$ & 1.164 & $(0.764-1.774)$ \\
\hline & High school & 18.4 & $(15.4-21.8)$ & 1.810 & $(1.192-2.747)$ \\
\hline & $\begin{array}{l}\text { Incomplete undergraduate } \\
\text { education or a higher level }\end{array}$ & 27.6 & $(21.4-34.8)$ & 3.052 & $(1.840-5.061)$ \\
\hline \multirow{2}{*}{ Monthly income } & $\leq \mathrm{R} \$ 500.00$ & 7.1 & $(5.4-9.3)$ & 1.000 & - \\
\hline & $\mathrm{R} \$ 501.00$ or more & 15.8 & $(14.3-17.5)$ & 2.454 & $(1.785-3.373)$ \\
\hline \multirow{2}{*}{$\begin{array}{l}\text { Lives with a } \\
\text { partner }\end{array}$} & No & 14.0 & $(12.7-15.5)$ & 1.000 & - \\
\hline & Yes & 9.8 & $(7.2-13.3)$ & 0.668 & $(0.464-0.960)$ \\
\hline \multirow{3}{*}{ Place of work } & Street & 11.5 & $(9.8-13.4)$ & 1.000 & - \\
\hline & Bars or nightclubs & 19.1 & $(15.5-23.3)$ & 1.820 & $(1.335-2.482)$ \\
\hline & Other indoor spaces & 13.9 & $(12.0-16.0)$ & 1.241 & $(0.971-1.586)$ \\
\hline \multirow{2}{*}{$\begin{array}{l}\text { Uses condoms } \\
\text { with clients }\end{array}$} & No & 6.9 & $(5.0-9.5)$ & 1.000 & - \\
\hline & Yes & 15.0 & $(13.6-16.6)$ & 2.384 & $(1.655-3.433)$ \\
\hline \multirow{2}{*}{$\begin{array}{l}\text { Accepts not } \\
\text { using condoms } \\
\text { with clients }\end{array}$} & Yes & 9.7 & $(8.0-11.8)$ & 1.000 & - \\
\hline & No & 15.5 & $(13.8-17.2)$ & 1.696 & $(1.311-2.194)$ \\
\hline \multirow{3}{*}{$\begin{array}{l}\text { Regular use of } \\
\text { health services }\end{array}$} & No & 9.6 & $(7.9-11.6)$ & 1.000 & - \\
\hline & Public & 14.8 & $(13.1-16.7)$ & 1.639 & $(1.275-2.108)$ \\
\hline & Private & 30.2 & $(23.1-38.5)$ & 4.079 & $(2.658-6.260)$ \\
\hline
\end{tabular}

Cl: confidence interval; OR: odds ratio.

In the multivariate analysis of the association between periodic HIV testing and the set of independent variables considered in the study (Table 5), the following factors were statistically significant: age group of 25 years or older; incomplete undergraduate education or a higher level; monthly income of R $\$ 501.00$ or more; consistent use of condoms with clients during vaginal sex; and having a usual source of care (public or private). 
Table 5. Multivariate analysis of the association between study variables and prevalence of periodic HIV testing in the last year prior to the survey. RDS-FSW, Brazil, 2016.

\begin{tabular}{|c|c|c|c|}
\hline \multirow{2}{*}{\multicolumn{2}{|c|}{$\begin{array}{l}\text { Variables } \\
\text { OR }\end{array}$}} & \multicolumn{2}{|c|}{ Periodic HIV testing in the last year } \\
\hline & & $95 \% \mathrm{Cl}$ & \\
\hline \multirow{2}{*}{ Age group } & 18 to 24 years old & 1.000 & - \\
\hline & 25 or older & 1.694 & $(1.275-2.252)$ \\
\hline \multirow{5}{*}{ Schooling level } & Some primary school & 1.000 & - \\
\hline & Some middle school & 0.753 & $(0.466-1.220)$ \\
\hline & Some high school & 1.054 & $(0.646-1.720)$ \\
\hline & High school & 1.426 & $(0.876-2.322)$ \\
\hline & $\begin{array}{l}\text { Incomplete undergraduate } \\
\text { education or a higher level }\end{array}$ & 2.415 & $(1.334-4.372)$ \\
\hline \multirow{2}{*}{ Monthly income } & $\leq \mathrm{R} \$ 500.00$ & 1.000 & - \\
\hline & $\mathrm{R} \$ 501.00$ or more & 1.921 & $(1.362-2.710)$ \\
\hline \multirow{2}{*}{ Lives with a partner } & No & 1.000 & - \\
\hline & Yes & 0.670 & $(0.447-1.003)$ \\
\hline \multirow{3}{*}{ Place of work } & Street & 1.000 & - \\
\hline & Bars or nightclubs & 1.276 & $(0.913-1.784)$ \\
\hline & Other indoor spaces & 0.819 & $(0.619-1.082)$ \\
\hline \multirow{2}{*}{$\begin{array}{l}\text { Uses condoms with } \\
\text { clients }\end{array}$} & No & 1.000 & - \\
\hline & Yes & 1.874 & $(1.215-2.890)$ \\
\hline \multirow{2}{*}{$\begin{array}{l}\text { Accepts not using } \\
\text { condom with clients }\end{array}$} & Yes & 1.000 & - \\
\hline & No & 1.191 & $(0.873-1.626)$ \\
\hline \multirow{3}{*}{$\begin{array}{l}\text { Regular use of health } \\
\text { services }\end{array}$} & No & 1.000 & - \\
\hline & Public & 1.732 & $(1.319-2.274)$ \\
\hline & Private & 2.965 & $(1.902-4.622)$ \\
\hline
\end{tabular}

Cl: confidence interval; OR: odds ratio.

\section{DISCUSSION}

The comparison of biological and behavioral studies performed in 2009 and 2016 in the group of FSWs showed an important increase of the HIV testing coverage in Brazil. The proportion of FSWs tested for HIV at least once in life grew from $64.4 \%$ to $77.3 \%$, while the testing coverage in the 12 months prior to the researches increased from $20.3 \%$ to $39.3 \%{ }^{15}$. 
However, despite the progress, the findings of this study show that the coverage of the periodic HIV testing among Brazilian FSWs still has much to improve. The testing coverage in the 12 months prior to the research was less than $40 \%$, and only $13.5 \%$ of the FSWs reported having been tested for HIV in the last year because they do it periodically.

Despite the recommendation for frequently getting tested for HIV among the so-called key-populations ${ }^{21}$, several countries also have low testing coverage among FSWs. In a socio-behavioral and serological survey conducted in 2012 in 4 provinces of the Dominican Republic, about one third of the FSWs did not know where to get tested for HIV, and only half had been tested at least once in the last 12 months ${ }^{22}$. In China, the coverage of getting tested for HIV at least once in life among FSWs is even lower (48\%) than the one found in Brazil ${ }^{23}$.

A meta-analysis study based on 36 articles of researches conducted in different countries about HIV testing among FSWs showed a great variation in the proportion of women who had been tested for HIV at least once throughout life and in the last year. In the group of analyzed countries, Benin and Canada stood out for high coverage; $87 \%$ in life and $65.3 \%$ and $75.1 \%$ in the last year, respectively - levels much higher than those found in Brazil.

The findings of low HIV testing coverage in the country corroborate results of other national studies. An investigation performed at the Brazilian border with French Guiana showed that $31.6 \%$ of the FSWs had never been tested for HIV ${ }^{25}$. In Fortaleza, Ceará, a study conducted with 402 FSWs revealed that $28.2 \%$ of them had never been tested for HIV, and $23.6 \%$ reported having had HIV testing more than one year before the research or not knowing when they had done it. The main barriers for getting tested were the perception that there was no risk of infection $(24.1 \%)$ and fear of discrimination if the result was positive $(20.5 \%)$. On the other hand, the main incentives for getting tested were the higher availability of test sites $(57.0 \%)$ and extended schedules in health units $(44.2 \%)^{26}$.

In this study, among the factors associated with a higher probability of getting tested for HIV in the last 12 months, a better level of education, the fact of living with a partner, working indoors, the association with other preventive practices - such as the consistent use of condoms-, and the regular use of health services, both public and private, stand out. The findings thus provide evidences that street FSWs, with low education and lower income are the most vulnerable and need specific interventions, aimed at raising awareness on risk exposure and on the importance of regular testing.

Regarding periodic HIV testing, the associations were somewhat different. While age was not significantly associated with HIV testing in the year preceding the study, younger FSWs were the ones with the lowest prevalence of periodic testing. Regarding the situation of living with a partner, the association was reversed, from protection (relative to the test in the last year) to risk (with periodic testing). A possible interpretation of this result is that FSWs who live with a partner get tested, usually, when they feel exposed or expose themselves to risks, and not because they are aware of the importance of periodic HIV testing. Recent studies in international literature also indicated that greater risk perception is associated with a greater chance of HIV testing ${ }^{24}$. 
The association between periodic HIV testing and the fact of having a usual source of care, whether public or private, shows, on the other hand, that the use of healthcare programs and services may impact the disposition of this population to periodically get tested for HIV, an important component for prevention strategies of FSWs around the world ${ }^{21}$.

However, factors such as stigma and discrimination are important barriers that hamper the regular use of health services ${ }^{27,28}$, especially due to the fear of public exposition and of the consequent negative attitudes of health professionals ${ }^{29}$. A previous publication, with the same data used in this study, showed that the non-disclosure of sexual work in health services may affect the HIV testing coverage, significantly lower among those who did not reveal being sex workers ${ }^{30}$.

Periodic HIV testing allows early diagnosis and immediate treatment of cases, reducing the chances of spreading the infection to the population. In Brazil, the difficulty in early detection of HIV infection impairs the benefits of the TasP (adopted since 2014), continuing HIV dissemination by individuals who do not know their serological status. Specifically in the case of FSWs, the expansion of early HIV diagnosis in this group would benefit the sex workers themselves and their clients, with positive repercussions in the general population.

\section{CONCLUSIONS}

Among the factors that contribute to the maintenance of the high load of HIV infection among FSWs is the lack of knowledge of the serological status, which has negative implications in coping with HIV/AIDS epidemy, both from the preventive and therapeutic point of view. Given the low HIV testing coverage among Brazilian FSWs, it is necessary to expand awareness campaigns, specifically among FSWs with low educational level and greater vulnerability, on the importance of periodic testing, as well as other preventive practices, in addition to encouraging regular health care, which are significantly associated with HIV testing coverage.

\section{REFERENCES}

1. Baral S, Todd CS, Aumakhan B, LloydJ, Delegchoimbol A, Sabin K. HIV among female sex workers in the Central Asian Republics, Afghanistan, and Mongolia: contexts and convergence with drug use. Drug Alcohol Depend. 2013;132(Suppl 1):13-6. https:// doi.org/10.1016/j.drugalcdep.2013.07.004

2. Li Y, Detels R, Lin P, Fu X, Deng Z, Liu Y, et al. Prevalence of HIV and STIs and associated risk factors among female sex workers in Guangdong Province, China. J Acquir Immune Defic Syndr. 2010;53(Suppl 1):S48-53. https:// doi.org/10.1097/ QAI.0b013e3181c7d72f
3. Vickerman P, Ndowa F, O’Farrell N, Steen R, Alary M, Delany-Moretlwe $S$. Using mathematical modelling to estimate the impact of periodic presumptive treatment on the transmission of sexually transmitted infections and HIV among female sex workers. Sex Transm Infect. 2010;86(3):163-8. https:// doi.org/10.1136/ sti.2008.034678

4. Ferreira-Júnior ODC, Guimarães MDC, Damacena GN, de Almeida WS, de Souza-Júnior PRB, Szwarcwald CL; Brazilian FSW Group. Prevalence estimates of HIV, syphilis, hepatitis B and C among female sex workers (FSW) in Brazil, 2016. Medicine 
(Baltimore). 2018;97(1S Suppl 1):S3-S8. https: / / doi. org/10.1097/ MD.0000000000009218

5. Shannon K, Strathdee SA, Goldenberg SM, Duff P, Mwangi P, Rusakova M, et al. Global epidemiology of HIV among female sex workers: influence of structural determinants. Lancet. 2015;385(9962):55-71. https: / / doi.org/10.1016/S0140-6736(14)60931-4

6. Brasil. Ministério da Saúde. Pesquisa de conhecimento, atitudes e práticas na população brasileira. Brasília, DF: Secretaria de Vigilância em Saúde. Departamento de IST, Aids e Hepatites Virais. Brasília, DF: Ministério da Saúde; 2016.

7. Chacham AS, Diniz SG, Maia MB, Galati AF, Mirim LA. Sexual and reproductive health needs of sex workers: two feminist projects in Brazil. Reprod Health Matters. 2007;15(29):108-18. https: / doi.org/ 10.1016/S0968-8080(07)29292-4

8. Lima FS, Merchán-Hamann E, Urdaneta M, Damacena GN, Szwarcwald CL. Factors associated with violence against female sex workers in ten Brazilian cities. Cad Saúde Pública. 2017;33(2):e00157815. http: / dx.doi.org/10.1590/0102-311x00157815

9. Barbosa-Jr A, Pascom ARP, Szwarcwald CL, Kendall C, McFarland W. Transfer of sampling methods for studies on most-at-risk populations (MARPs) in Brazil. Cad Saúde Pública. 2011;27(Suppl 1):s36-44. http:/ / dx.doi.org/10.1590/S0102-311X2011001300005

10. Szwarcwald CL, Bastos FI, Lacerda R, Gravato N, Chequer PN, Castilho E. The relationship of illicit drug use to use to HIV infection among commercial sex workers in the city of Santos, São Paulo, Brazil. Int J Drug Policy. 1998;9:427-36.

11. Brasil. Ministério da Saúde. Coordenação Nacional de DST e Aids. Avaliação da efetividade das ações de prevenção dirigidas às profissionais do sexo, em três regiões brasileiras. Brasília, DF: Ministério da Saúde; 2004.

12. Szwarcwald CL, Barbosa Júnior A, Souza Jr. PRB, Lemos KR, Frias PG, Luhm KR, et al. HIV testing during pregnancy: use of secondary data to estimate 2006 test coverage and prevalence in Brazil. Braz J Infect Dis. 2008;12(3):167-72. http:// dx.doi.org/ 10.1590/S1413-86702008000300002

13. Malta M, Magnanini MM, Mello MB, Pascom AR, Linhares Y, Bastos FI. HIV prevalence among female sex workers, drug users and men who have sex with men in Brazil: a systematic review and meta-analysis. BMC Public Health. 2010;10(1):317. https: / doi.org/ 10.1186/1471-2458-10-317

14. Szwarcwald CL, de Souza Júnior PR, Damacena GN, Junior AB, Kendall C. Analysis of data collected by RDS among sex workers in 10 Brazilian cities, 2009: estimation of the prevalence of HIV, variance, and design effect. J Acquir Immune Defic Syndr. 2011;57(Suppl 3):S129-35. https:/ / doi.org/10.1097/ QAI.0b013e31821e9a36

15. Szwarcwald CL, de Almeida WS, Damacena GN, de Souza-Júnior PRB, Ferreira-Júnior ODC, Guimarães MDC; Brazilian FSW Group. Changes in attitudes, risky practices, and HIV and syphilis prevalence among female sex workers in Brazil from 2009 to 2016. Medicine (Baltimore). 2018;97(1S Suppl 1):S46-S53. https: / doi.org/10.1097/MD.0000000000009227

16. Brasil. Ministério da Saúde. Departamento de Vigilância, Prevenção e Controle das IST, do HIV/ Aids e das Hepatites Virais. Protocolo clínico e diretrizes terapêuticas para atenção integral às pessoas com infecções sexualmente transmissíveis (IST) [Internet]. Brasília, DF; 2015 [cited 2019 Apr 5]. Available from: http:/ / bit.ly/2VoJbzH

17. Joint United Nations Programme on HIV/Aids (Unaids). 90-90-90: an ambitious treatment to help end the Aids epidemic [Internet]. Geneva; 2014 [cited 2019 Apr 5]. Available from: http:/ / bit.ly/30g0rL1

18. Montaner JS, Lima VD, Harrigan PR, Lourenço L, Yip B, Nosyk B, et al. Expansion of HAART coverage is associated with sustained decreases in HIV/ Aids morbidity, mortality and HIV transmission: the "HIV Treatment as Prevention" experience in a Canadian setting. PLoS One. 2014;9(2):e87872. https:// doi. org/10.1371/journal.pone.0087872

19. Batona G, Gagnon MP, Simonyan DA, Guedou FA, Alary M. Understanding the intention to undergo regular HIV testing among female sex workers in Benin: a key issue for entry into HIV care. J Acquir Immune Defic Syndr. 2015;68(Suppl 2):S206-12. https: / / doi.org/10.1097/QAI.0000000000000452

20. IBM SPSS Statistics for Windows [computer program]. Version 21.0. Armonk (NY): IBM Corp; 2012.

21. World Health Organization. Consolidated guidelines on HIV testing services. Geneva; 2015.

22. Johnston LG, Bonilla L, Caballero T, Rodriguez M, Dolores Y, de la Rosa MA, et al. Associations of HIV testing, sexual risk and access to prevention among female sex workers in the Dominican Republic. Aids Behav. 2017;21(8):2362-71. https:/ / doi.org/10.1007/ s10461-016-1616-2

23. Hong Y, Zhang C, Li X, Fang X, Lin X, Zhou Y, et al. HIV testing behaviors among female sex workers in Southwest China. Aids Behav. 2012;16(1):44-52. https: / / doi.org/10.1007/s10461-011-9960-8

24. Tokar A, Broerse JEW, Roura M, Blanchard J. HIV Testing and counseling among female sex workers: a systematic literature review. Aids Behav. 2018;22(8):2435-57. https: / / doi.org/10.1007/ s10461-018-2043-3 
25. Parriault MC, van Melle A, Basurko C, GaubertMarechal E, Macena RH, Rogier S, et al. HIV-testing among female sex workers on the border between Brazil and French Guiana: the need for targeted interventions. Cad Saúde Pública. 2015;31(8):1615-22. https: / / doi.org/10.1590/0102-311X00138514

26. Martins TA, Kerr L, Macena RHM, Mota RS, Dourado I, Brito AM, et al. Incentivos e barreiras ao teste de HIV entre mulheres profissionais do sexo no Ceará. Rev Saúde Pública. 2018;52:64. https: / / doi.org/10.11606/ S1518-8787.2018052000300

27. King EJ, Maman S, Bowling JM, Moracco KE, Dudina $\mathrm{V}$. The influence of stigma and discrimination on female sex workers' access to HIV services in St. Petersburg, Russia. Aids Behav. 2013;17(8):2597-603. https: / / doi.org/10.1007/s10461-013-0447-7

28. Wang Y, Li B, ZhengJ, Sengupta S, Emrick CB, Cohen MS, et al. Factors related to female sex workers' willingness to utilize VCT service: a qualitative study in Jinan city, northern China. Aids Behav. 2009;13(5):866-72. https: / / doi.org/10.1007/s10461-008-9446-5
29. Ghimire L, Smith WCS, van Teijlingen ER. Utilisation of sexual health services by female sex workers in Nepal. BMC Health Serv Res. 2011;11:79. https: / / doi.org/10.1186/1472-6963-11-79

30. Dourado I, Guimarães MDC, Damacena GN, Magno L, Souza-Jr PRB, Szwarcwald CL, et al. Sex work stigma and non-disclosure to health care providers: data from a large RDS study among FSW in Brazil. BMC Int Health Hum Rights. 2019;19(1):8. https: / / doi.org/10.1186/s12914-019-0193-7

Received on: 02/06/2019

Final version presented on: 04/05/2019

Approved on: 04/12/2019

Author's contribution: Brito AM and Szwarcwald CL conceived the article, elaborated the text and analyzed the data. Damacena GN contributed with the writing of the article and with data analysis. Dourado IC participated in the elaboration of the text. All authors reviewed and approved the final version of this study. 